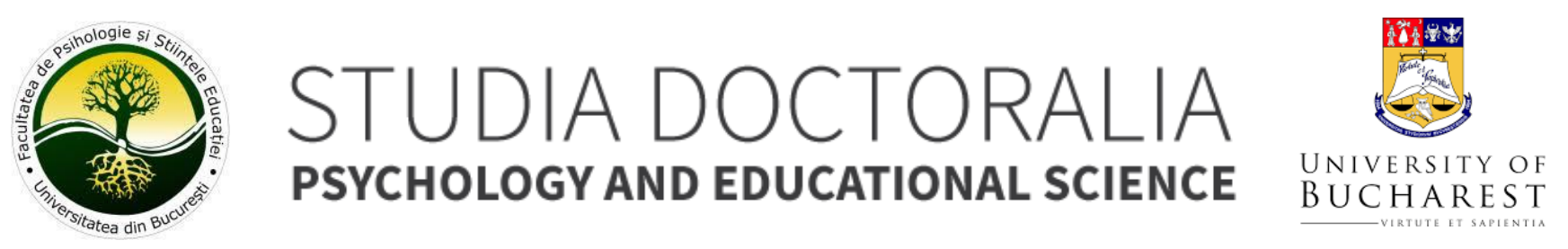

\title{
The role of personality in the relationship between financial stress and well-being in young people
}

\author{
Chipeșiu Ana Maria
}

University of Bucharest

\section{ARTICLE INFO}

Article history:

Received 10-July-2020

Accepted 28-August-2020

Available online 01-November-2020

This article should be cited as: Chipeșiu, A. M. (2020). The role of personality in the relationship between financial stress and well-being in young people. Studia Doctoralia. Psychology and Educational Science, 11(2), 81-92. https://doi.org/10.47040/sd/sdpsych.v11i2.114

This is an open access article under the CC BY license (http://creativecommons.org/licenses/by/4.0/).

Corresponding author at: University of Bucharest, Department of Psychology, 90 Panduri Av, Bucharest, RO.

Tel.: +40 (0) 31-425.34.45

E-mail address: anachipesiu@gmail.com

\section{ABSTRACT}

The present study is aimed to study the moderating role of personality in the relationship between financial stress and well-being in young people in Romania. The sample consisted of 168 young people aged between 20 and 35 years old ( $M=22.05, A S=2.72$ ), of which 116 are female $(69 \%)$ and 52 male (31\%). To measure the variables, we used InCharge Financial Distress/Financial Well-Being Scale, The Satisfaction with Life Scale and questionnaires of ten items each (Markers Big Five) that are part of the collection of items of the IPIP-Ro project. The results showed that only Openness to experience, as a personality factor, has a moderating effect on the relationship between financial stress and well-being. The novelty of the study consists in capturing the relationships between personality, financial stress and well-being of young people in Romania. Few Romanian studies analyzed the moderating effect of personality in the relationship between the two variables mentioned above. The present study can contribute to the development of financial education programs, the aim being to reduce financial stress and increase the well-being of young people through strategies for efficient management of personal resources.

Keywords: personality, well-being, financial stress

\section{INTRODUCTION}

The demands of the ever-evolving modern world are often overwhelming, especially for young people looking to make their way in life. Most aspects that represent the standards of a decent and fulfilled life require the allocation of considerable financial resources and some financial stability, which is often a problematic issue.
Referring to Maslow's pyramid, the very first category of physiological needs that included the needs of food, water or shelter, are sectors that can be covered by modern man with financial resources. Also, for many young people who are at the next level of development, the first house or the first car purchased is important, all of which represent needs 
related to personal safety (Milheim, 2012). The discrepancy and inconsistency between the avalanche of demands on the environment and the financial balance of each can prevent the efficient functioning of individuals in society who face the anguish of daily living.

Financial problems can affect the health, mental balance and significant interpersonal relationships in everyone's life, all due to frustration and the accumulation of negative emotions that perform a maladaptive function. Caring for money can lead to symptoms of anxiety or depression that affect personal harmony and self-esteem. A small income that does not cover the real needs of modern man and the high cost of unforeseen situations, exceed the financial power of many people, turning the future into something uncertain and frightening. People's financial insecurity is therefore a real problem of modern life and adjacent to it are many other aspects that hinder the tendency towards self-actualization of each.

Thus, starting from the previous information, our intention is to analyze the relationship between financial stress and well-being in young people in Romania. Wellbeing means a fusion between the emotional component, characterized by evaluations, cognitions and positive emotions, and the behavioral component, the effective functioning of people in society (Huppert, 2009). In other words, well-being represents people's satisfaction in relation to their living conditions, being influenced by contexts and subjective interpretations that people give to the objective events around them.

Given how financial stress affects most sectors present in the life of the individual in contemporary society, researching the impact it has on well-being will hopefully bring more knowledge in understanding the relationship between these two constructs. As there are currently no studies to substantiate the relationship between these two variables on the population of young people in Romania, this article aims to provide an overview of how financial stress affects the well-being and the magnitude of this issue.

The present study became even more interesting when personality appeared in the equation. Over time, in specialized writings, this concept is quite controversial, because there is no generally valid definition accepted by all theorists. All theories offer new and impressive perspectives on the personality that unravel small mysteries behind human nature. The study of personality is extremely important, as evidenced by all the decades-long research that covers small parts of the complexity of the subject, continuing with recent research that hopes to further discern man as an entity. Today personality is a relatively stable set of preferences, attitudes, dispositions and tendencies of a person to behave in a certain way in different contexts, unlike other individuals, who in similar situations would react and think completely differently (Ones, Viswesvaran , \& Dilchert, 2005 in lliescu, Popa, \& Dimache, 2015).
In such a way that the personality sculpts each of us unique ways of thinking and reacting to different circumstances, it is a challenge for the present study, our intention being to identify the role of personality in the relationship between financial stress and well-being of young Romanians. This research aims to discover how personality influences the feeling of financial stress and its impact on well-being, in the context in which personality individualizes the way people adapt to the demands of the environment in which we live. The most prominent model of personality at this time in the literature is the Big Five Model, which includes five facets of personality, each with distinct characteristics (lliescu, Popa, \& Dimache, 2015). Based on these five personality factors, we aim to identify individual differences among young people that cause them to react differently to financial stress, thus influencing their wellbeing and satisfaction with their living conditions.

Therefore, understanding the complexity of the constructs discussed above, their detachment from the demands of modern life offers the study the opportunity to generate an overview of what financial stress means and how it influence the well-being, especially taking into account the different way of reacting to external stimuli, all this applied to young people in Romania. With this study we hope to gain more knowledge of human nature assailed by all the requirements of the environment in which modern man develops.

\section{Financial stress}

Financial behavior has become a well-studied field over time, in previous research being positively associated with financial satisfaction (Shim, Xiao, Barber, \& Lyons, 2009), financial relationships with family members, and financial well-being, with health, academic success and also with satisfaction with life in general (Serido, Shim, \& Tang, 2013). Thus, following recent research, Xiao and O'Neill (2016) focus on financial capacity. This concept is understood by researchers as a complex of components that include subjective and objective knowledge, those financial behaviors that can be considered desirable and the subjective perception of their ability to manage money or personal financial resources.

According to a 2003 survey (Survey of Consumer Finance) about $76 \%$ of families have credit cards, and about $44 \%$ of families are in debt (Norvilitis et al., 2006). The average amount of debt per family was US $\$ 1,900$. The problem raised by Norvilits et al. (2006) is that the debts of families and students are similar. In their study, the same authors mention that the debts and the financial stress have negative repercussions on the psychological well-being of young students. The large debts that young students have are associated with unsuccessful money management and low self-esteem, or even dropping out of school (Norvilitis et al., 2006). 
For many universities in different countries, financial stress and concerns about students' financial resources have become priorities for action. In a study conducted by Heckman, Lim and Montalto in 2014, it was shown that among students, who were the subjects of the study, $71 \%$ reported psychological discomfort felt due to financial stress. The authors argue that two of the main stressors were lack of finances to participate in various regular student activities and expectations of having very high debts after graduation (Heckman, Lim, \& Montalto, 2014).

Previous studies argue that one of the five fundamental stressors among young students is financial stress (Trombitas, 2012 in Heckman, Lim, \& Montalto, 2014). One definition of financial stress is the inability to cover financial obligations that led to negative psychological and emotional effects (Northern et al., 2010 in Heckman, Lim. \& Montalto, 2014).

Recently, there have been increasing debts among young people, especially students, which attracts a psychological discomfort associated with financial stress. Lack of money and debt have a negative impact on the psychological well-being of young people. All these aspects are associated with a decrease in the capacity to organize financial resources and a low self-esteem. It is very important that all these aspects are taken into account, as there are also cases in which young people give up further studies for financial reasons. Poor mental health is reported in these young people, in addition to which an increasingly reduced social functioning is added (Norvilitis et al., 2006).

Research suggests that financial stress occurs primarily due to an income that cannot support all expenses, but also due to inefficient income management. Sound financial management requires a well-calculated management of resources, the implementation of a financial plan, giving up social comparison with others and, last but not least, resisting the urge to buy things that prove useless in the future (Gathergood, 2012).

Studies that have looked at the effects of financial stress on young employees have concluded that financial stress is one of the leading causes of employee losses and lack of productivity in the United States. Stress does not come from a single cause, it has several sources, including the inability to financially cover all necessary expenses. Stress can also be caused by various disabilities or psychological or social stressors. Most stressors are associated with both psychological and social problems that affect interpersonal relationships, but also the workplace (Bailey, Woodiel, Turner, \& Young, 1998).

Financial stress is perceived to be the most important source of psychosocial stress, because every daily activity nowadays involves financial resources and their management. Financial problems often affect the productivity of people caught in the workplace and interpersonal relationships (Williams, Haldeman, \& Cramer,
1996). Previous research suggests that financial stress plus financial worries about various aspects of daily life have an impact on personal satisfaction and job satisfaction (Boles, Johnson, \& Hair, 1997 in Bailey et al., 1998) .

Studies confirm that there is a strong link between education about managing financial resources and their effective management. For example, a study mentions the existence of a correlation between people's financial education and the planning of the financial resources they will receive during retirement. Retirement finance planning is not an action that anyone can take, but can be managed by a specialist. A study by Gerrans and Hershey (2017) found that financial education leads people to take a longterm interest in this field and to seek financial advice for both personal and financial issues. These results support the importance of financial education that leads people to make wiser decisions when it comes to money management (Gerrans \& Hershey, 2017 in Alsemgeest, 2019).

\section{Well-being}

Well-being is a fusion between feeling good and effectively behave adaptively in different situations. This concept should not be understood in an absolutist way, because individuals can not have a state of well-being at any time, but it's about a good management of negative emotions, which contributes to the maintenance of wellbeing in general. Well-being in the literature includes several aspects, not only positive emotions such as happiness or contentment, but also emotions such as interest, involvement, trust or affection. To function effectively, in a psychological way, means discovering and working on a certain potential that helps maintain coordination of life, developing a meaning or purpose in life or experiencing positive interpersonal relationships over time (Huppert, 2009).

Research shows that people who are generally happy tend to function and cope better with life's challenges than less happy people. Also, happy people are more productive and more involved in the social environment, and some studies have concluded that happy people also have higher incomes (Judge, Thoresen, Bono, \& Patton, 2001 in Huppert, 2009). Ryan and Deci (2001) showed that people who are happy and have high levels of well-being have more positive cognitions, which in turn contribute to the emergence of positive emotions (Ryan \& Deci, 2001 in Huppert 2009).

Previous studies cannot say clearly whether there is a causal relationship between positive cognitions and positive emotions. The truest evidence comes from experimental studies in which techniques for inducing a certain state have shown that experiencing a state of well-being can increase attention, activate other cognitive processes, generate more ideas (Fredrickson \& Branigan, 2005 in Huppert, 2009) and such people are much more flexible in thinking and creative 
compared to people experiencing negative or neutral states (Ashby, Isen, \& Turken, 1999 in Huppert, 2009).

Positive emotions can be a consequence of certain cognitive processes or behaviors, but at the same time they can be a cause of them. Research in the field, both experimental and observational, has shown that increased subjective well-being is associated with intrinsic motivation, goal setting (Kasser \& Ryan, 1996 in Huppert, 2009), achieving goals and setting goals in line with personal values (Sheldon \& Elliot, 1999 in Huppert, 2009), not with adopting a behavior of avoiding responsibilities (Elliot, Sheldon, \& Church, 1997 in Huppert, 2009). What also contributes to the well-being of people in general is the participation in various social events or involvement in a community. These aspects are associated with much higher levels of happiness, well-being and life satisfaction (Helliwell \& Putnam, 2005; Putnam, 2000).

To better understand how emotions work and how people reach a level of subjective well-being, neuroscience studies provide some useful information. Thus, we know that the circuit of emotions in the brain is a complex one involving the structures of the prefrontal cortex, amygdala, hippocampus, anterior cingulate cortex and insular cortex. These structures are interconnected by processing information, and will generate an emotional or behavioral response (Huppert, 2009). Research over time has focused mainly on the prefrontal cortex, as this structure responds differently to positive or negative emotions depending on the area that is activated. Davidson and his colleagues (1922) concluded that there are very large differences between the activated areas of the prefrontal cortex depending on the emotions felt by different people. They showed that in people who feel positive emotions the left area is activated more predominantly than the right one in the waking state, compared to people who feel negative emotions in which the right area is activated (Davidson, 1992, in Huppert, 2009).

People in general are very different in how they invest emotionally in the events around them, so some people may feel predominantly positive emotions and others negative emotions (Huppert, 2009). The best way to understand the differences between people emotionality is to analyze the evolution of the human brain. Compared to other organs, the human brain is designed to respond to all the conditions in the environment in which a child develops. Thus, the period of early childhood is a sensitive one for the development of the brain, especially the age of two years (Dawson, Ashman, \& Carver, 2000 in Huppert, 2009). Moreover, the development of the frontal lobes, those that process and are responsible for processing emotions or planning emotional control, can extend into adulthood (Keverne, 2005, 2008 in Huppert, 2009).

What influences the well-being and intellectual capacity of people is the social environment from childhood. Thus the emphasis is on the relationship between mother and child. Studies on this topic, conducted over time, have provided evidence that, even in childhood, the presence of positive emotions has been associated with adaptive cognitions and prosocial behaviors, which will create a basis for lifelong resilience (Huppert, 2009 ).

There is specialized research that explores this field and suggests that well-being is influenced by genotype. Research says that transmitted genes have an effect on the development of well-being and resilience. Recent studies have shown that a certain part, called the short allele, present in the serotonin transporter gene is vulnerable to depression if there are certain activating events. On the other hand, there is also a long allele in the serotonin transporter gene that can influence increased resilience (Kendler et al., 2005; Caspi et al., 2003, cited in Huppert, 2009).

\section{Financial stress and well-being}

Danes and Retting (1993) have shown that people who perceive their income as inadequate for their needs report negative feelings and a low level of satisfaction with their standard of living (Danes \& Rettig, 1993, in Prawitz et al. al., 2006). Such negative reactions felt due to financial conditions significantly reduce the well-being of people (Mills et al., 1992).

To a large extent, a fundamental part of psychological well-being is satisfaction with many aspects of life. Of course, these aspects include the financial part. Research for more than thirty years has explored subjective and objective aspects to describe the financial condition of individuals and families (Prawitz et al., 2006). Numerous studies in the literature have examined the factors that contribute to well-being in general and have shown that financial stress is a very good predictor of low levels of wellbeing (Blumstein \& Schwartz, 1983; Mirowsky \& Ross, 2003).

Exposure to stressors generates the release of cortisol, the stress hormone. Individual differences in wellbeing, including self-esteem or emotional style, can change the way people respond to stress. Different amounts of cortisol are released during a day. A healthy model involves a high rate immediately after waking up, with a decrease at the end of the day (Clow, 2004 in Huppert, 2009). Several studies have shown that this healthy pattern of cortisol release has been associated with high levels of well-being, along with optimism and positive affect (Steptoe, Gibson, Hamer, \& Wardle, 2007 in Huppert, 2009).

Financial stress has been described by researchers over time as a financial pressure following today's environmental demands. Economic stress is understood as a personal assessment that involves analyzing the financial adequacy about income, economic worries and concerns all these aspects compared to what each person considers to be ideal. Economic stress is often associated with negative physical or psychological aspects. It can lead to problems 
with alcohol abuse, possibly even depression, and greatly reduce well-being (Voydanoff, 1984 in Kim \& Garman, 2003).

One of the main sources of mental discomfort is financial stress and in various studies is associated with poor mental and physical health (Alsund, Larm, Starrin, \& Nilsson, 2014). Financial stress is understood as the inability to cover the basic expenses of a normal day. The mental discomfort felt after financial stress is a strong predictor of the onset, but also the persistence of mental disorders (Weich \& Lewis, 1998, in Alsund, et al, 2014). Current research in the literature has shown that people who experience financial stress, but have low social support, have increased chances of up to six or seven times higher to have a low psychological well-being, associated with many psychosomatic problems. Also in this direction, in people who reported financial stress, but social support from close people was present, the chances of having a low wellbeing were much lower, and Alsund et al. (2014) in their study suggest that social support acts as a barrier against the negative symptoms caused by financial stress.

Reported at the individual level, research shows that economic difficulties (restraints regarding desires for material purchases or low incomes that do not cover daily expenses) are associated with an increased risk for health problems (Pihl \& Starrin 1998 in Starrin, Aslund, \& Nilsson, 2009). Mental health problems are more common among people who are experiencing financial difficulties, for example, cannot afford to pay monthly bills or do not have financial reserves for possible unforeseen situations (Pihl \& Starrin 1998 in Starrin, Aslund, \& Nilsson, 2009). Data from various researches suggest that the mental health of young people is influenced by the economic resources they have (Hagquist 1998; Ostberg, 2001, in Starrin, Aslund, \& Nilsson, 2009).

With data from an online questionnaire was analyzed the impact of medical students' participation in unpaid internships. More than a hundred students participated in this study, and the researchers concluded that most respondents have problems when it comes to transportation costs, extra meals, appropriate clothing for work plus other additional purchases. Most study participants, in order to cope economically, used the savings set aside, borrowed or managed their finances very carefully so as to lessen the effects of financial stress. However, the study suggests that unpaid student participation in internships affects short-term financial well-being. As they learn and gain work experience, their resistance to future financial stressors increases, so that they become more confident in their own strengths (Grand-Smith \& Zwaan, 2019).

The increase in university fees plus the non-payment of the activity in the hospitals while the students are still in the faculty and the lack of financial support makes more and more students face problems with financial stress, as they have to live from day to day, trying to cover the expenses involved in the faculty and daily expenses (Devlin, James \& Grigg, 2008; Wray \& McCall, 2007). Studies support the idea that financial circumstances and related concerns have a negative impact on students' emotional and health status, in other words, financial stress has a negative impact on people's psychological well-being (Bemel et al., 2016; Britt et al., 2016, in Grand-Smith \& Zwaan, 2019), but also on academic performance (Joo et al., 2008; Northern et al., 2010 in Grand-Smith \& Zwaan, 2019).

Taking into account the above, we assume that:

$\mathrm{H1}$. The high level of financial stress is associated with a low level of well-being.

Personality, financial stress and well-being

Managing financial resources in most cases involves the adoption of specific behaviors, and the authors of a study conducted in 2014 give some examples such as: paying bills on time, keeping money for emergencies, pension funds or avoiding very large loans (Brown \& Taylor, 2014). Also, the standard predictors of financial behavior are usually socioeconomic status, education and intellectual capacity. Of course, in addition to these, there are others such as, for example, personality traits, motivation or principles related to life in general (Roberts, 2009).

To understand how people manage their finances, Donnelly, lyer, and Howell (2012) argue that individual differences and the values that individuals establish regarding the issue of financial resources have an impact on well-being. As mentioned in their 2012 study, the authors argue that the personality traits in the Big-Five Model represent the best model for understanding personality, but few studies investigate personality profiles and how they make their mark. on how individuals organize and plan their finances (Donnelly, lyer, \& Howell, 2012).

One aspect that cannot be overlooked is the involvement that personality has in the entire system regarding the organization of finances. Norvilitis et al. (2006) identified certain personality traits that could be associated with debt accumulation and thus financial stress, but these results tend to be controversial, as the authors state that there is no specific trait that is certainly associated with a poor organization of financial resources, but it depends on the intersection of several factors and variables.

Related to this topic, there are various specialized studies that focus on demonstrating that anxiety given by financial stress is a different construct compared to depression or generalized anxiety. Financial anxiety is described as a psychosocial behavior that results in wrong attitudes toward the effective management of personal finances (Shapiro \& Burchell, 2012, cited in Grable et al., 2019). The way decisions about certain investments induce a state of stress and anxiety has been a topic of interest for some researchers. Anxiety greatly changes the way decisions are made. Anxious people are much more likely to 
avoid making a decision if the investment seems risky. Gambetti and Giusberti (2012) found that anxiety was negatively associated with money-raising behavior (Gambetti \& Giusberti, 2012, in Grable et al. 2019).

Resource management generally involves some specific behaviors, such as paying bills on time, saving money or avoiding too much borrowing (Brown \& Taylor, 2014). Of course, all these behaviors are manifested depending on the particularities of each individual. Donnelly, lyer and Howell (2012) show that good resource management is associated with less materialism, in other words, with a weaker desire to buy as many things as possible. There are specialized studies in which it is shown that people who tend to buy various things, without being absolutely necessary, are more prone to accumulating debt and adopting a relaxed attitude towards them. These people also report the tendency to have loans in as many installments as possible and are followers of compulsive shopping (Watson, 2003).

Among the features of the Five-Factor Model, Neuroticism and Extraversion, as they are conceptualized and described in this taxonomy, are those traits that have been shown to be predictors of financial stress (Eysenck 1967; Tian et al., 2018, in Kim , Furlong, \& Dowdy, 2019).

\section{METHODOLOGY}

\section{Participants and procedure}

This study involved 168 young people aged between 20 and 35 years $(M=22.05, S D=2.72)$, of which 116 are female $(69 \%)$ and 52 male (31\%). Participants were contacted online through social networks. A short presentation of the questionnaire and its purpose was made, and then according to the condition of being between the ages of 20 and 35, they were invited to complete the questionnaire. The completion of the form took about 15 minutes, at the beginning the respondents were asked to provide the initials of the name and surname, age and gender, followed by the actual completion of it.

The first section of the online form contained informed consent. By marking the "agree" button, the young people expressed their desire to participate in the research, agreeing to the processing of the data provided. Also, the subjects were notified that the information provided is confidential, their usefulness being used for academic purposes.

The collected data was organized and analysed using the statistical analysis softwares, IBM.SPSS 24 (IBM Corp, 2016) and Jamovi (the jamovi project, 2019).

\section{Instruments}

Financial stress / financial well-being. The InCharge Financial Distress / Financial Well-Being Scale was used to
Also, the results of their study indicated that another suitable predictor for the predisposition to feel stress is Consciousness (Kotov et al. 2010, in Kim, Furlong, \& Dowdy, 2019). Personality traits are the best predictors for debt accumulation. Norvilits et al. (2006) point out that among the students, those with low self-esteem also experienced discomfort regarding their financial situation. Moreover, those who compulsively spent also reported low self-esteem (Norvilitis et al., 2006). In the same study, several aspects related to self-control are brought to light. Those with poor self-control have more debt and have proven unable to manage the satisfaction and pleasure that comes with every time they buy different things. O'Guinn and Faber (1989) showed that people who are compulsive about shopping, the chances of having debts and being unable to manage their finances to meet monthly expenses are higher (O'Guinn \& Faber, 1989 in Norvilits et al., 2006).

Given the above, one objective of the study is to identify the relationships between personality, financial stress and well-being. Therefore, we will analyze the moderating effect of personality in the relationship between financial stress and well-being, thus assuming that:

$\mathrm{H} 2$. Personality factors moderate the relationship between financial stress and well-being.

assess participants' perceived level of financial stress (Prawitz et al., 2006). The questionnaire includes eight short questions about the financial situation in general, the answers being given on a Likert scale, where 1 - very low / never and 5 - very high / always. Some examples of items are: What do you think is the level of your financial stress right now? or How often do you worry about monthly expenses? .

Well-being. Well-being in young people was measured using The Satisfaction With Life Scale (Diener, Emmons, Larsen, \& Griffin, 1985). Well-being means a cognitive process of evaluating experiences. The authors mention that well-being, implicitly satisfaction with life is based on comparisons whose standards are set individually, do not come from external sources (Diener et al., 1985). This scale has five items, and the answers are given on a Likert scale, where 1 means total disagreement and 5 means total agreement. Participants are asked to read the statements carefully and then to indicate the number corresponding to the agreement or disagreement felt in relation to that statement. Some representative items are: In general, my life is close to my ideal or So far I have achieved the important things I wanted in my life.

Personality. The five personality factors (conscientiousness, agreeableness, emotional stability, extraversion, intellect / imagination) were measured by questionnaires of ten items each (Big Five Markers). The 
items in the questionnaires are part of the IPIP-Ro project's collection of items, and have been translated independently by three different translators. Like the original model, the answers to the items are given on a Likert scale where 1 means total disagreement and 5 means total agreement, and participants are asked to rate the statement. Examples of items would be for Extraversion: I am the soul of the party., For Pleasantness: I am interested in people, for Conscientiousness: I am very attentive to details., For Emotional Stability: I am relaxed most of the time. And Intellect / Imagination: I use difficult words, hard to understand (lliescu, Popa, \& Dimache, 2015).

\section{RESULTS}

\section{Descriptive statistics}

Table 1. Descriptive statistics

\begin{tabular}{|c|c|c|c|c|c|c|c|c|c|c|}
\hline & $\mathrm{M}$ & SD & $a$ & $E$ & A & $C$ & ES & 0 & FS & WB \\
\hline$E$ & 34.70 & 7.90 & .87 & 1 & & & & & & \\
\hline A & 42.50 & 5.34 & .78 & .02 & 1 & & & & & \\
\hline C & 34.50 & 6.83 & .72 & -.02 & $.23^{* *}$ & 1 & & & & \\
\hline ES & 28.51 & 8.62 & .74 & $.22^{* *}$ & .06 & $.18^{*}$ & 1 & & & \\
\hline 0 & 40.20 & 5.40 & .78 & $.28^{* *}$ & .09 & -.03 & .08 & 1 & & \\
\hline FS & 22.83 & 6.70 & .85 & $-.23^{* *}$ & -.13 & $-.21^{* *}$ & $-.40^{* *}$ & $-.17^{*}$ & 1 & \\
\hline WB & 23.61 & 6.40 & .85 & $.33^{* *}$ & $.24^{\star *}$ & $.19^{*}$ & $.42^{\star *}$ & .13 & $-.55^{\star \star}$ & 1 \\
\hline
\end{tabular}

${ }^{* *} . p<.01,{ }^{*} . p<.05$

E- Extraversion, A-Agreeableness, C-Conscientiousness, ES-Emotional stability, O-Openness to experience, FS-Financial stress, WB-Well-being

\section{Hypothesis testing}

$\mathrm{H1}$. The high level of financial stress is associated with a low level of well-being.
In order to test this hypothesis, a simple linear regression analysis was performed.

Table 2. Simple linear regression for financial stres predicting well-being

\begin{tabular}{|c|c|c|c|c|c|c|}
\hline & & $B$ & SE & Beta & $\mathrm{t}$ & $p$ \\
\hline & (Constant) & 35.61 & 1.46 & & 24.34 & .00 \\
\hline 1 & Financial stress & -.53 & .06 & -.55 & -8.55 & .00 \\
\hline
\end{tabular}

It is observed that the financial stress is responsible for $30.6 \%$ of the well-being variation, the regression equation being statistically significant, $F(1,166)=73.07, p<.01$. Financial stress has a negative association to well-being, $\beta$ $=-.55, \mathrm{t}(168)=-8.55, \mathrm{p}<.01$ so we can state that $\mathrm{H} 2$ is supported by the analyzed data.
H2. Personality factors moderate the relationship between financial stress and well-being.

In order to test this hypothesis, a series of moderations were performed having as predictor the financial stress, as a dependent variable the well-being and as moderators, alternatively, the five personality factors. 


\section{$95 \%$ \\ Confidence \\ Interval}

Estimate SE Min. $\quad$ Max. $\quad z \quad p$

\begin{tabular}{lcccccc} 
FINSTR & -.50 & .06 & -.60 & -.37 & -8.17 & .00 \\
EXT & .20 & .05 & .07 & .27 & 3.36 & .00 \\
FINSTR ** & & & & & & \\
EXT & -.01 & .01 & -.02 & .01 & -1.05 & .29 \\
\hline
\end{tabular}

Extraversion fails to moderate the relationship between financial stress and well-being, $\beta=-.01, \mathrm{Cl} 95 \%(-.02, .01), \mathrm{z}$ $=-1.05, p=.29$.

Table 4. Moderation analysis for agreeableness

\section{$95 \%$ \\ Confidence \\ Interval}

Estimate SE Min. $\quad$ Max. $\quad z \quad p$

$\begin{array}{lcccccc}\text { FINSTR } & -.50 & .06 & -.62 & -.38 & -8.34 & .00 \\ \text { AGR } & .20 & .07 & .06 & .35 & 2.75 & .07\end{array}$

FINSTR *

AGR

$\begin{array}{lll}-.01 & .01 & -.03\end{array}$

$.02 \quad-.48 \quad .63$

Agreeableness fails to moderate the relationship between financial stress and well-being, $\beta=-.01, \mathrm{Cl} 95 \%(-.03, .02)$, $z$ $=-.48, p=.63$.

Table 5. Moderation analysis for conscientiousness

\section{$95 \%$ \\ Confidence \\ Interval}

Estimate SE Min. Max. $\quad$ $\quad p$

\begin{tabular}{lllllll} 
FINSTR & -.51 & .06 & -.63 & -.40 & -8.37 & .00 \\
CON & .07 & .06 & -.05 & .19 & 1.18 & .24 \\
FINSTR * & & & & & & \\
CON & -.01 & .01 & -.02 & .02 & -.07 & .95 \\
\hline
\end{tabular}

Conscientiousness fails to moderate the relationship between financial stress and well-being, $\beta=-.01$, Cl95\%($.02, .02), z=-.07, p=.95$.

\begin{tabular}{lcccccc}
\hline & \multicolumn{6}{c}{$\begin{array}{c}95 \% \\
\text { Confidence } \\
\text { Interval }\end{array}$} \\
& Estimate & SEMin. & Max. & $\mathbf{Z}$ & $\mathbf{p}$ \\
\hline FINSTR & -.47 & .06 & -.55 & -.32 & -7.35 & .00 \\
EMSTAB & .17 & .05 & .08 & .26 & 3.75 & .00 \\
FINSTR $*$ & & & & & & \\
EMSTAB & .01 & .01 & -.01 & .01 & .11 & .91 \\
\hline
\end{tabular}

Emotional stability fails to moderate the relationship between financial stress and well-being, $\beta=.01$, Cl95\%($.01, .01), z=.11, p=.91$.

Table 7. Moderation analysis for openness to experience

\section{$95 \%$ \\ Confidence \\ Interval}

Estimate SEMin. Max. $\quad \mathbf{z} \quad \mathbf{p}$

\begin{tabular}{lcccccc} 
FINSTR & -.52 & .06 & -.63 & -.40 & -8.53 & .00 \\
OP & .04 & .07 & -.10 & .19 & .59 & .56 \\
$\begin{array}{l}\text { FINSTR* } \\
\text { OP }\end{array}$ & -.02 & .01 & -.05 & -.01 & -.82 & .04 \\
\hline
\end{tabular}

Openness to experience moderates in a small extent the relationship between financial stress and well-being, the moderation estimate being $\beta=-.02, \mathrm{Cl} 95 \%(-.05,-.01)$, $z=-$ $.82, p<.05$. The interaction between financial stress and openness has a negative effect on well-being.

Table 8. Moderation estimates for different values of openness to experience

\section{$95 \%$ \\ Confidence \\ Interval}

Estimate SE Min.

Max. $\quad Z \quad p$

\begin{tabular}{lccccc} 
Average & -.52 & .06 & -.64 & -.40 & $-8.45<.001$ \\
Low $(-$ & & & & & \\
1SD) & -.41 & .09 & -.58 & -.24 & $-4.81<.001$ \\
$\begin{array}{l}\text { High } \\
(+1 S D)\end{array}$ & -.62 & .08 & -.78 & -.46 & $-7.50<.001$ \\
\hline
\end{tabular}

At low levels of openness to experience the moderation estimate is $-.41, \mathrm{Cl} 195 \%$ (-. 58, - . 24), $z=-4.81, p<.01$, at medium levels of openness to experience the moderation estimate is -.52 , Cl95 \% (-. 64, - . 40), $z=-8.45, p<.01$, and 
at high levels of openness to experience the moderation estimate is $-.62, \mathrm{Cl} 95 \%(-.78,-.46), z=-7.50, p<.01$.

Given these results, we state that hypothesis $\mathrm{H} 2$ is supported only to a small extent by the analyzed data. Only one personality factor moderates the relationship between financial stress and well-being, and this is openness to experience.

\section{DISCUSSION}

The objective of this research was to identify the relationships between personality, financial stress and wellbeing. The first hypothesis of the study, according to which we assumed that high level of financial stress is associated to a low level of well-being, was supported by the analyzed data. All the demands of the environment in which we live, the needs and necessities that can be covered with the help of financial resources can explain why young people feel much more financial stress, which causes a decrease in well-being. Previous studies show that people with lowincome find it more difficult to accomplish all their daily needs and desires, have a low level of satisfaction with their living conditions (Danes \& Rettig, 1993, cited in Prawitz et al. al., 2006). Therefore, financial stress has a negative effect on well-being, which is explained by all the current demands and daily needs. This inconsistency between environmental demands and own financial resources may explain why financial stress causes poor well-being. In specialized studies, financial satisfaction has been explained as a subjective assessment, taking into account the satisfaction related to the financial part, but also to the subjective well-being (Diener \& Biswas-Diener, 2002; Van Praag, Frijters, \& Carbonell, 2003), all of which represent components of the perceived economic position (Joo \& Grable, 2004; Kalleberg \& Marsden, 2012).

The financial aspirations and perspectives that people generally have on money are closely related to well-being. Kasser and Ryan (1993) aimed to study the differences between people for whom the financial part was a dominant component in their lives and those who had humanitarian goals (significant interpersonal relationships, helping others, personal development, etc.). The authors concluded that personnel who focused on the financial side were much more unhappy and dissatisfied with their living conditions as opposed to those who focused on humanitarian purposes (Kasser \& Ryan, 1993, cited in Tatzel, 2002).

Some research argues that efforts to obtain a higher salary, extra work, overtime in the office, ultimately lead to negative effects on well-being (Fischer, 2008; Schnittker, 2008). Most studies in the literature claim that salary, implicitly financial satisfaction, is an important predictor of well-being (Hastings, 2019). People who feel that their income does not cover their usual daily needs carry negative feelings and have a low level of satisfaction with their lifestyle (Danes \& Rettig, 1993 in Prawitz et al., 2006). Also, authors such as Blumstein and Schwartz (1983) or Mirowsky and Ross (2003) after examining the factors that contribute to psychological well-being in general, argue that financial stress is a strong predictor of low levels of well-being scales.

Regarding the second hypothesis of the study, only openness to experience as a personality factor has a moderating effect on the relationship between financial stress and well-being. This brings a negative contribution in the relationship between the two variables, people with high scores for openness to experience feeling more financial stress and having a lower level of well-being. People with high scores for openness are more analytical and realistic, more accurately estimating risks from a financial point of view (Roccas, Lilach, Shalom, \& Ariel, 2002). Openness to experience is extremely compatible with universalism, which means understanding and tolerance for people and appreciation of aesthetics, but also with motivational goals, autonomy of thought and behavior. These aspects can be taken into account in interpreting the results, thus explaining why openness have a negative contribution to the relationship between financial stress and well-being (Roccas et al., 2002).

Financial stress and its negative effects on well-being are a serious problem among young people, the present study providing an explanation of what personality brings in the relationship between the variables mentioned above. Although only one of the five factors of personality in the Big Five Model had a moderating effect, the practical implications of the study represent suggestions for increasing the well-being of young people, thus reducing financial stress by learning new behaviors like efficient management of financial resources. The study also offers a new perspective of the relationships between the research variables studied on a sample of young Romanians aged between 20 and 35 years.

\section{Practical implications}

The results of the study highlight the importance of financial knowledge related to money management in young people. The participation of young people in different courses of management of personal financial resources could contribute to the reduction of financial stress, they adapt much more adequately to the demands coming from the environment, being much more satisfied in relation to their living conditions. Courses should focus on learning an effective way to manage money, but also on saving and investing smart financial resources (Zhu \& Chou, 2018).

It is crucial for young people to be aware of the efficient management of financial resources, as in the future these issues will make the difference between adults who function adapted to the demands of the environment, and adults who encounters both physical and mental health problems. Therefore, the implementation in schools or universities of 
study programs focused on the efficient management of finances could contribute to increasing well-being and reducing financial stress among young people in Romania.

Young adults who are more informed and financially prepared will feel much more confident and optimistic about their future and will know how to deal with financial stressors more effectively. Therefore, the results of the study could provide options for various counseling programs that would help reduce financial stress among young students or young people who have their first job, respectively their first salary. Previous studies have confirmed that students with better self-efficacy and optimism feel less financial stress, having a higher well-being (Gutter \& Copur, 2011).

Participating in a financial counseling course or program can develop a new way of thinking and productive behaviors of managing financial resources, which could reduce financial stress. Of course, many other studies suggest that financial education makes people more realistic about financial problems, seeking advice to solve them (Gerrans \& Hershey, 2017 in Alsemgeest, 2019). The obtained results indicate the relevance of financial education among young people in Romania, so that they acquire strategies through which they adopt much wiser decisions when it comes to managing personal financial resources.

\section{Limitations and future directions}

It is very important to mention some limits and future directions of the study. A first limit of the study is the small number of participants which makes it impossible to generalize the results for all young people in Romania. The higher the number of participants, the more accurate the results. For the future, a larger sample is recommended to identify results as close to reality as possible.

Also, another limitation of the study refers to the fact that the measuring instrument for the level of financial stress felt by the participants (InCharge Financial Distress / Financial Well-Being Scale Prawitz et al., 2006), was translated into

\section{REFERENCES}

Alsemgeest, L. (2019). The Relationship Between Job Satisfaction, Financial Stress and Sufficient Retirement Savings of Near-Retirement Pastors in Southern Africa. Review of Religious Research, 61(2), 119-133. https://doi.org/10.1007/s13644-019-00366-1

Alsund C., Larm P., Starrin B., \& Nilsson W. K., (2014). The buffering effect of tangible social support on financial stress: influence on psychological well-being and psychosomatic symptoms in a large sample of the adult general population. International Journal for Equity in Health, 13, 85. http://www.equityhealthj.com/content/13/1/85

Bailey, W. C., Woodiel, D. K., Turner, M. J., \& Young, J. (1998). The Relationship of Financial Stress to Overall
Romanian by the authors of this study. This could affect the construct validity of the questionnaire, the items not being the expression of a representative sample for the Romanian population. For future studies, a questionnaire adapted to the Romanian population is preferable, with items representative for the entire field.

The constructs were measured online by self-reporting, so in order to create the most desirable image the subjects could have easily manipulated the answers. This could affect the validity of the sample. Another important limit is represented by the sample composed mainly of female subjects $(69 \%)$, compared to male ones $(31 \%)$. This limit also makes it impossible to generalize the results to the target population. A sample of approximately equal male and female participants could more accurately show gender differences in financial stress and well-being.

\section{Personal contribution}

The results of this study contribute to the understanding of the relationship between personality, financial stress and well-being in young people in Romania. Financial resources and their management represent a delicate subject for many people due to the multitude of demands coming from the society. They also influence most of the decisions we make during our financial existence. Analyzing the moderating role of personality, a variable that highlights the particularities of each individual, in the relationship between financial stress and well-being in the context of a period of life in which financial decisions and their consequences become increasingly important, brings more knowledge to specialized literature from Romania. Thus, there is a gap in the knowledge about the research variables analyzed on young Romanians, the present study aimed to deepen the relationships between these constructs, providing an overview of the moderating effect of personality in the relationship between financial stress and well-being.

Stress and Satisfaction. Personal Finances and Worker Productivity, 2(2).

Bergner, R. M. (2020). What is personality? Two myths and a definition. New Ideas in Psychology, 57, 100759. https://doi.org/10.1016/j.newideapsych.2019.100759

Blumstein, P. W., \& Schwartz, P. (1983). American couples: Money, work, sex. New York: William Morrow.

Brown, S. \& Taylor, K. (2014). Household finances and the "Big Five" personality traits. Journal of Economic Psychology, 45, 197-212. doi:10.1016/j.joep.2014.10.006. Crețu Z. R. (2012). Perspective clasice în psihologia personalității. Bucharest: Editura Universitară. 
Devlin, M., James, R. \& Grigg, G., (2008). Studying and working: a national study of student finances and student engagement. Tertiary Education and Management 14(2), 111-122

Donnelly, G., lyer, R., \& Howell, R. T. (2012). The Big Five personality traits, material values, and financial well-being of self-described money managers. Journal of Economic Psychology, 33(6), 1129-1142. https://doi.org/10.1016/j.joep.2012.08.001

Diener, E., Larsen R. J., Griffin S., \& Emmons, R. A. (1985.). The Satisfaction With Life Scale. Journal of Personality Assessment, 49(1).

Diener, E., \& Biswas-Diener, R. (2002). Will money increase subjective well-being? Aliterature review and guide to needed research. Social Indicators Research, 57, 119-169. Fischer, C. S. (2008). What wealth-happiness paradox? A short note on the American case. Journal of Happiness Studies, 9(2), 219-226.

Gathergood, J. (2012). Self-control, financial literacy and consumer over-indebtedness. Journal of Economic Psychology, 33(3), 590-602.

Grant-Smith, D., \& de Zwaan, L. (2019). Don't spend, eat less, save more: Responses to the financial stress experienced by nursing students during unpaid clinical placements. Nurse Education in Practice, 35, 1-6. https://doi.org/10.1016/j.nepr.2018.12.005

Grable, J. E., Archuleta, K. L., Ford, M. R., Kruger, M., Gale, J., \& Goetz, J. (2019). The Moderating Effect of Generalized Anxiety and Financial Knowledge on Financial Management Behavior. Contemporary Family Therapy. https://doi.org/10.1007/s10591-019-09520-x

Gutter, M., \& Copur, Z. (2011). Financial Behaviors and Financial Well-Being of College Students: Evidence from a National Survey. Journal of Family and Economic Issues, 32(4), 699-714. doi: 10.1007/s10834-011-9255-2

Hastings, O. P. (2019). Who Feels It? Income Inequality, Relative Deprivation, and Financial Satisfaction in U.S. States, 1973-2012. Research in Social Stratification and Mobility 60, 1-15.

Huppert, F. A. (2009). Psychological Well-being: Evidence Regarding its Causes and Consequences. Applied Psychology: Health and Well-Being, 1(2), 137-164. https://doi.org/10.1111/j.1758-0854.2009.01008.x

Heckman, S., Lim, H., \& Montalto, C. (2014). Factors Related to Financial Stress among College Students. Journal of Financial Therapy, 5(1). https://doi.org/10.4148/1944-9771.1063

Helliwell, J., \& Putnam, R. D. (2005). The social context of well-being. In F.A. Huppert, N. Baylis, \& B. Keverne (Eds.), The science of well-being (pp. 435-459). Oxford: Oxford University Press.

IBM Corp. Released 2016. IBM SPSS Statistics for Windows, Version 24.0. Armonk, NY: IBM Corp
Iliescu, D., Popa, M., \& Dimache, R. (2015). Adaptarea românească a Setului Internaţional de Itemi de Personalitate: IPIP-Ro. Psihologia Resurselor Umane, 13, 83-112

Joo, S.-H., \& Grable, J. E. (2004). An exploratory framework of the determinants of financial satisfaction. Journal of Family and Economic Issues, 25, 25-50.

Kim, J., \& Garman, E. T. (2003). Financial Stress and Absenteeism: An Empirically. Derived Model. Financial Counseling and Planning, 14.

Kim, E. K., Furlong, M. J., \& Dowdy, E. (2019). Adolescents' Personality Traits and Positive Psychological Orientations: Relations with Emotional Distress and Life Satisfaction Mediated by School Connectedness. Child Indicators Research, 12(6), 1951-1969. https://doi.org/10.1007/s12187-019-9619-y

Kahneman, D., Diener, E., \& Schwarz, N., (1999). Wellbeing: The foundations of hedonic psychology. Russell Sage Foundation.

Kalleberg, A., \& Marsden, P. V. (2012). Labor force insecurity and U.S. work attitudes, 1970s-2006. In P. V. Marsden (Ed.). Social trends in American life (pp. 315-337). Princeton: Princeton University Press.

Milheim, K. L. (2012). Toward a Better Experience: Examining Student Needs in the Online Classroom through Maslow's Hierarchy of Needs Model. MERLOT Journal of Online Learning and Teaching, 8(2).

Mills, R. J., Grasmick, H. G., Morgan, C. S., \& Wenk, D. (1992). The effects of gender, family satisfaction, and economic strain on psychological well-being. Family Relations, 41, 440-446.

Mirowsky, J., \& Ross, C. (2003). Social causes of psychological distress (2nd ed). New York: Aldine de Gruyter.

Norvilitis, J. M., Merwin, M. M., Osberg, T. M., Roehling, P. V., Young, P., \& Kamas, M. M. (2006). Personality Factors, Money Attitudes, Financial Knowledge, and Credit-Card Debt in College Students. Journal of Applied Social Psychology, 36(6), 1395-1413. https://doi.org/10.1111/j.0021-9029.2006.00065.x

Putnam, R.D. (2000). Bowling alone. New York: Simon \& Schuster.

Prawitz, A. D., Garman, E. T., Sorhaindo, B., O'Neill, B., Kim, J., \& Drentea, P. (2006). InCharge Financial Distress/Financial Well-Being Scale: Development, Administration, and Score Interpretation. Financial Counseling and Planning, 17(1).

Roberts, B. W. (2009). Back to the future: Personality and assessment and personality development. Journal of Research in Personality, 43(2), 137-145.

Roccas, S., Lilach S., Shalom H. S., \& Ariel K. (2002). The Big Five Personality Factors and Personal Values. Personality and Social Psychology Bulletin 28(6), 789-801. 
Shim, S., Xiao, J. J., Barber, B. L., \& Lyons, A. C. (2009). Pathways to life success: A conceptual model of financial well-being for young adults. Journal of Applied Developmental Psychology, 30(6), 708-723.

Serido, J., Shim, S., \& Tang, C. (2013). A developmental model of financial capability $A$ framework for promoting a successful transition to adulthood. International Journal of Behavioral Development, 37(4), 287-297.

Starrin, B., Åslund, C., \& Nilsson, K. W. (2009). Financial Stress, Shaming Experiences and Psychosocial III-Health: Studies into the Finances-Shame Model. Social Indicators Research, 91(2), 283-298. https://doi.org/10.1007/s11205008-9286-8

Schnittker, J. (2008). Diagnosing our national disease: Trends in income and happiness,1973 to 2004. Social Psychology Quarterly, 71(3), 257-280.

Wray, N. \& McCall, L., (2007). Money matters: students' perceptions of the costs associated with placements. Medical. Education. 41(10), 975-981.

Twenge M., \& N. Martin (2020). Gender Differences in Associations between Digital Media Use and Psychological Well-Being: Evidence from Three Large Datasets. Journal of Adolescence 79, 91-102.
Tatzel, M. (2002). Money Worlds' and Well-Being: An Integration of Money Dispositions, Materialism and PriceRelated Behavior. Journal of Economic Psychology 23(1), 103-26.

Van Praag, B. M. S., Frijters, P., \& Carbonell, F. A. (2003). The anatomy of subjective well-being. Journal of Economic Behavior \& Organization. https://doi.org/10.1016/S01672681(02)00140-3

Williams, F.L., Haldeman, V., \& Cramer, S. (1996). Financial concerns and productivity. Financial Counseling and Planning, 7, 147-156. Willlams, K.J.

Watson, J. J. (2003). The relationship of materialism to spending tendencies, saving, and debt. Journal of Economic Psychology, 24, 723-739. http://dx.doi.org/10.1016/j.joep. 2003.06.001.

Xiao, J. J., \& O'Neill, B. (2016). Consumer financial education and financial capability. International Journal of Consumer Studies, 40(6), 712-721.

Zhu, A. F., \& K. Chou. (2018). Development of Financial Capacity in Adolescents. Child and Adolescent Social Work Journal 35(3), 309-15. 